\title{
ENVIRONMENTAL SECURITY MANAGEMENT FROM THE PERSPECTIVE OF ENVIRONMENTAL DISPUTES RESOLUTION
}

\begin{abstract}
One of the responsibilities of the state is to ensure the safety of its citizens. This applies to every category of safety, including environmental security. Thus, ensuring security - i.e. the protection of vital interests of individuals and the state against various types of threats, both internal and external - allows identifying the most important security components, which are human individuals and their rights and freedoms, as well as the state including its constitutional system, sovereignty and the entire territory. In turn, environmental security management, understood as a process to achieve the relevant objectives set out in this area, should also be perceived within the formula of conflict resolution. The resolution of environmental conflicts can be implemented using different methods: contractual, mediation-and-conciliation, or adjudication, The last case is the most common in practice because disputes tend to be settled via lawsuits, which terminate with a legally binding decision giving one of the parties a sense of "victory". However, due to the dynamics of legislative changes, it is necessary to take note of a legal instrument that has been in force for a long time, as it enables conflicted parties to settle disputes with mutual success. Given that each of the mentioned forms of resolving environmental disputes is driven by different mechanisms, particular models will be analyzed, thus providing the subject of discussion in this article.
\end{abstract}

Keywords: environmental security, security management, threats, disputes

\section{INTRODUCTION}

Security management should be perceived as a complex process. It consists primarily of authorized state (nationwide and local governments) and private (non-governmental organizations) entities taking decisions aimed at achieving certain strategic goals in the area of safety. In Poland, where the basic items of security policy tend to include: protection of sovereignty and independence, maintaining the inviolability of borders and territorial integrity of the state, ensuring security of citizens, especially human rights and fundamental freedoms, creating undisturbed conditions for civilizational and economic development, as well as improving the well-being of citizens, protection of national heritage and national identity,

\footnotetext{
${ }^{1}$ Marcin Jurgilewicz, PhD, Assoc. Prof. at the Department of Law and Administration at the Faculty of Management of the Rzeszów University of Technology, 35-084 Rzeszów, ul. Akademicka 2, bud. Arcus; e-mail: m.jurgilewicz@ prz.edu.pl. ORCID: 0000-0003-2243-2165.

Dr hab. Marcin Jurgilewicz, prof. PRz, Katedra Prawa i Administracji, Wydział Zarządzania, Politechnika Rzeszowska, 35-084 Rzeszów, ul. Akademicka 2, bud. Arcus; e-mail: m.jurgilewicz@ prz.edu.pl. ORCID: 0000-0003-2243-2165.
} 
or defense and promotion of the Polish state's interests, there is also a justified need to adopt more specific goals, in particular ensuring access to natural resources and preserving the natural environment, including at global level, which essentially falls within the scope of environmental security.

Accordingly, resolution of disputes that commonly arise in various spheres and areas of public life becomes one of the prerequisites for good management of environmental security. This aspect, therefore, has become the main research goal in this article.

\section{ENVIRONMENTAL SECURITY AND DISPUTES}

Nowadays, the term security can be considered special in that it is correlated with the development of the state and the mutual interaction of its structures. In fact, the perception of security is influenced by many factors, such as civilizational and technical progress or ongoing implementation of innovative solutions, while its condition can be measured based on various types of threats, the dynamics of which depend on different determinants (the economy, social awareness etc.). Because of that, an increase in interest in security issues can be observed, mainly in the non-military area.

Security, which means, in a certain simplification, the protection of the vital interests of individuals and the state against both internal and external threats allows indicating the most important components of security, namely: the individual and their rights and freedoms, as well as the state with its constitutional system, sovereignty and territory. Not without significance is the fact that the state is to protect the independence and integrity of its territory, as well as to ensure safety of its citizens, which is reflected in the initial provisions of the Constitution, i.e. in Chapter 1 art. 5 of the Constitution of the Republic of Poland, which states that "the Republic of Poland shall safeguard the independence and integrity of its territory and ensure the freedoms and rights of persons and citizens, the security of the citizens, safeguard the national heritage and shall ensure the protection of the natural environment pursuant to the principles of sustainable development", and which assumes "the universal legal principle that the process of interpretation and application of law is the basis for the interpretation of legal texts"2.

Security is divided differently by academics in the literature. These divisions include: international and national, internal and external, plus the concept of security, being also one of the most important values for various entities (states, nations), may also be either objective or subjective due to the close connection of this term with the state of social perception.

In turn, taking into account the relationship between the state of the actual threat and its perception, four cases can be distinguished. In the first case, there is a lack of security that occurs during a significant, real and external threat, and the perception of this threat is correct (adequate). The second case refers to an obsession when there is an insignificant threat which is mistakenly perceived as significant. Another case concerns false security and takes place when the external threat is serious and its perception is low. The last case is a sense

${ }^{2}$ K.A. Wojtaszczyk, A. Majerska-Sosnowska (ed.), Bezpieczeństwo państwa. Wybrane problemy, Warsaw 2009, p. 214. Cf. M. Jurgilewicz, Administracja bezpieczeństwa i obronności - wybrane aspekty [in:] Wspólna polityka bezpieczeństwa i obronności. Implikacja dla Polski, A. Letkiewicz, Z. Nowakowski, J. Rajchel (eds.), Warsaw 2011, p. 596. 
of security, which takes place when the external threat is insignificant and its perception is correct $^{3}$.

Generally speaking, security means "assurance of existence and survival, possession and operation and development of the entity, and the result of lack of threats and their proper perception; it also arises from the creative activity of a given entity and at the same time is a social process which varies in time" 4 . However, it should be added that the essence of security "comes down to a broadly understood safety conditioning the guarantee of integral survival and the freedom of development of individuals" 5 .

Security applies to almost every area of life, thus becoming a category of increasing importance to both citizens and state authorities, which also stems from the fact of Poland's accession to the EU. Due to the fact that the entirety of state security covers two aspects, internal and external (international), it is possible to identify within internal security those elements being the most important for society as well as individuals ${ }^{6}$. They include public, economic and energy security, as well as the increasingly popular environmental security, which is one of the priorities from the perspective of the state's activities. Environmental security, the essence of which is mainly to provide the people with a desired and effective protection through activities of competent entities, also concerns interpersonal skills in resolving disputes arising within the concerned territory ${ }^{7}$.

On the other hand, in the area of natural environment, environmental disputes may spring from various situations. Most often, however, their source can be traced back to human activities aimed at using limited natural resources to satisfy particular interests, often with harm to third parties, which implies a contradiction between interests and values of parties to the dispute. Thus, among the reasons of environmental conflicts, one can distinguish in particular those related to the clash of interests of various environments (e.g. local communities, public administration or non-governmental organizations) in the field of environment and the use of its resources, conflicts arising from historical conditions and the mentality of the people in terms of views on the essence of environmental protection and the manner of their demonstration, as well as those related to the normative definition of the parties' rights and obligations with respect to the use of natural benefits, such as the dispute over the ski lift to Gubałówka ${ }^{8}$.

Dispute resolution, meanwhile, intends to find a solution that satisfies individual interests of conflicted parties, trying to put an end to the dispute as such.

\section{METHODS OF RESOLVING ENVIRONMENTAL DISPUTES}

Given the ways in which disputes can be settled, on the basis of law one can point to model methods (styles), which are more or less successfully used in practice. These are:

${ }^{3}$ K.A. Wojtaszczyk, A. Majerska-Sosnowska (ed.), Bezpieczeństwo..., p. 17.

4 Ibidem, p. 18

${ }^{5}$ M. Jurgilewicz, Wymiar unijnego bezpieczeństwa po wejściu w życie Traktatu z Lizbony [in:] UE-NATO - Strategiczne problemy bezpieczeństwa, red. nauk. T. Compa, J. Rajchel, K. Załęski, Dęblin 2012, p. 294-295.

${ }^{6}$ Ibidem, p. 295.

${ }^{7}$ See W. Niemiec, A. Pacana, O. Jurgilewicz, M. Jurgilewicz, Aspekty zarzadzania środowiskiem w praktyce inżynierskiej, Rzeszów 2013, p. 49-61.

${ }^{8}$ Ibidem, p. 392. 
contractual (relatively rarely used), mediation-and-conciliation, arbitration, and adjudication', whereas it is adjudication that is the most commonly applied because the resulting dispute is resolved via a lawsuit that ends with a legally binding decision, ensuring that one of the parties experiences a sense of victory. However, due to the dynamics of legislative changes, it is worth taking note of a legal instrument that has been in force for a long time, as it enables conflicted parties to settle the dispute with mutual success. Thanks to the mediation-and-conciliation method, the parties can submit for settlement any type of dispute (including environmental) with the participation of an independent person - a mediator, mainly acting through the mediation institution. The essence of mediation is, apart from concluding a settlement between the parties, also to avert the conflict as such which is once its source has been recognized.

Undoubtedly, mediation is successful when skillfully led by the mediator, who is able to either prepare the ground for mitigating the dispute or resolve it effectively. The mediator should, therefore, be a neutral person who derives no benefits from the final settlement of the dispute ${ }^{10}$.

In practice, environmental conflict resolution will concern both civil (including economic) and administrative matters. Accordingly, in broadly understood civil matters (mainly regarding property claims), the basic regulations regarding mediation have been set out in art. 183(1) - 183(15) of the Act of 17 November 1964. The Code of Civil Procedure ${ }^{11}$, while in the case of administrative matters, mediation was outlined in the Act of 14 June 1960. The Code of Administrative Procedure ${ }^{12}$ (art. 96a - 96n), as well as in the Act of 30 August 2002 on proceedings before administrative courts ${ }^{13}$ (art. 115-117). It should be added that mediation can also be applied in the field of criminal law, in conflicts arose from environmental reasons, while maintaining the conditions enabling its conduct ${ }^{14}$.

Another model method of dispute resolution is arbitration, under which the parties not only retain unlimited influence on the choice of a third party - an arbitrator, but also have the freedom to choose the procedure regarding negotiations and rules for resolving the dispute. Nevertheless, the decision of the arbitrator deciding the dispute is imperative and binding on the parties, and may also be subjected to a forced execution procedure ${ }^{15}$.

In essence, arbitration applies when the parties establishing a legal relationship indicate that in the event of a dispute, it will be submitted to the arbitration court, or in the absence of such an agreement, will be concluded with the consent of the parties to submit the dispute to the arbitrator. The parties may specify the number of arbitrators in the contract, and in the absence of such, an arbitration court composed of three arbitrators should be appointed. Submission of a dispute for amicable settlement requires a contract of parties, which should

\footnotetext{
9 L. Morawski, Wstęp do prawoznawstwa, Toruń 2001, p. 37.

${ }^{10}$ See M. Jurgilewicz, A. Dana, Mediacja jako sposób rozwiazzywania sporów prawnych, Warsaw 2015.

11 Journal of Laws of 2018, item 1360, as amended.

12 Journal of Laws of 2017, item 1257, as amended.

13 Journal of Laws of 2018 r., item 1302, as amended. Law on Proceedings before Administrative Courts.

${ }^{14}$ See art. 23a of the Act of 6 June 1997. The Code of Criminal Procedure (Journal of Laws of 2017, item 1904, as amended).

${ }^{15}$ L. Morawski, Wstęp..., p. 37.
} 
be made in writing ${ }^{16}$. In turn, pursuant to art. 1157 of the Code of Civil Procedure, parties to disputes may submit for settlement property cases or disputes over non-proprietary rights, unless there is a special provision which provides otherwise, except for alimony cases. If, therefore, a dispute concerns civil matters, the background of which is an environmental conflict, it could then be resolved via arbitration (the so-called arbitration clause).

Environmental security management in the aspect of resolving environmental disputes seems to be often related to the effective conduct of administrative proceedings. In practice, disputes are relatively frequent, the source of which is the decision of the public administration body regarding investments such as building a waste incineration plant, building a motorway, or expropriating real estate for the purpose of a legally protected facility. Normally, administrative proceedings take place in two stages - proceedings before a public administration authority, or proceedings before an administrative court. Accordingly, in proceedings before a public administration body, pursuant to art. 96a $\S 1$ and 3 of the Code of Administrative Procedure, mediation may be carried out in the course of such proceedings as long as the nature of the case allows it, and its purpose is to clarify and consider the factual and legal circumstances of the case, as well as make arrangements for its settlement within the applicable law, including issuing a decision or reaching a settlement. Mediation can, therefore, be an important element of the legal process, especially in matters of particular complexity, such as establishing conditions or issuing building permits, particularly in the case of socially controversial infrastructural investments where the participant in the proceedings is a social organization whose statutory goals prevision, for example, protection of the environment ${ }^{17}$. It is worth noting that mediation can be important in the resolution of disputes in which there are many parties involved, as well as when there is a chance to reach a settlement in cases in which the authority intends to issue a decision to the addressee's expecting an appeal, as well as in cases in which an appeal was lodged against a decision issued in first instance ${ }^{18}$.

Due to the fact that mediation is voluntary and its participants may be both the body conducting the proceedings or the party, or parties, to this proceeding, in accordance with art. 96b § 1-4 of the Code of Administrative Procedure, it may be held ex officio or at the request of the parties in which a mediator may be appointed. However, in the notice of the possibility of conducting mediation, the public administration body asks the parties to consent to its conducting and select a mediator, which takes place within fourteen days from the date of delivery of the notification. The notification includes instructions on the principles of mediation and its costs, in particular information on the voluntary nature of mediation, including the right to stop mediation at any stage of the process without adverse consequences for a given party. On the other hand, in the situation when mediators agree to carry out mediation jointly, the public administration body issues a decision on referral to mediation in which the mediator selected by the mediation participants is indicated, and if not, the mediator chosen by the public administration authority is indicated, having the appropriate knowledge and skills in conducting mediation in cases of a given type ${ }^{19}$. In

\footnotetext{
${ }^{16}$ See art. $1161 \S 1-3$ The Code of Civil Procedure, art. $1162 \S 1-2$ The Code of Civil Procedure, and art. 1169 § $1-2$ The Code of Civil Procedure.

${ }^{17}$ M. Jurgilewicz, Mediacja w postępowaniu administracyjnym [in:] Bezpieczeństwo. Prawo. Polityka, M. Jurgilewicz, T.Z. Leszczyński, N. Malec (red.), Kraków 2017, p. 75.

18 M. Jurgilewicz, Mediacja w administracji publicznej, Rzeszów 2018, p. 59.

19 Ibidem, p. 60.
} 
addition, the public administration body, when referring the matter to mediation, postpones considering the case for up to two months, albeit on a compliant application of its participants or for other important reasons, this period may be extended, however no longer than a month. Regardless, in accordance with art. $35 \S 5$ of the Code of Administrative Procedure, the duration of mediation is not included in the duration of the proceedings ${ }^{20}$.

Settlement of an administrative matter in accordance with the mediation arrangements takes place when, as a result, arrangements are made to settle the matter within the limits of the applicable law. Then, the public administration body handles the matter in accordance with these arrangements, contained in the protocol on the course of mediation. However, documents and other materials that are not included in the files of proceedings disclosed in the mediation by its participants, if they do not constitute the basis for settling the matter in accordance with the provisions contained in the minutes, are also not contained in the files of the proceedings altogether. Therefore, mediation in an administrative procedure is an important element of dispute resolution, and it mainly facilitates the determination of the facts of the case, which does not conflict with the authorities' obligations in the area of exhaustive meeting and consideration of all evidence and taking all necessary steps to clarify the facts ${ }^{21}$.

On the grounds of proceedings before administrative courts, pursuant to art. 115 § 1-2 Law on Proceedings before Administrative Courts, at the request of the complainant or the body which is submitted prior to the date of the hearing, a mediation procedure may be conducted, the purpose of which is to clarify and consider the factual and legal circumstances of the case and to make arrangements by the parties for how to settle it within the applicable law. It may also be carried out despite the parties' request to conduct such proceedings. Taking into account the scope of the judicial control of the administration, as defined in art. $3 \S 2$ Law on Proceedings before Administrative Courts, mediation may include a category of complaints about administrative decisions, acts or activities in the field of public administration regarding entitlements or obligations under the law, acts of bodies of local governments and their associations, other than acts of local law in matters of public administration, inactivity or lengthy proceedings, or other decisions on matters in which the provisions of special laws provide for judicial review, and apply the measures set out in these provisions. Mediation proceedings may be conducted in most categories of complaints, the decision of which is in the jurisdiction of the administrative court, although it does not include complaints about acts of supervision over the activities of local-government bodies.

In court and administrative proceedings, mediation commences, in principle, when a complaint is filed. According to art. $50 \S 1$ Law on Proceedings before Administrative Courts, a complaint can be filed by anyone with a legal interest, a prosecutor, Civil Rights Commissioner, Children's Rights Commissioner, and a social organization within its statutory activity, in matters concerning the legal interests of other people, if it participated in administrative proceedings, as well as any other entity who is granted the right to lodge a complaint by the law. Since there are no statutory restrictions on the form of initiating mediation, the request for it may be included as one of the elements in the complaint, by way of response to the complaint in the case of the body, as well as in a separate procedural letter, which must meet the formal requirements of a plead. In accordance with art. 46 and

\footnotetext{
${ }^{20}$ Ibidem, p. 60-61.

${ }^{21}$ Ibidem, p. 61-62.
} 
57 Law on Proceedings before Administrative Courts, the letter should contain the following items: the name of the court to which it is addressed, full name or registered name of the parties, their legal representatives and proxies; designation of the type of writing; the operative part of the application or statement; determination of a law violation or legal interest; designation of the authority whose inactivity or lengthy proceedings are the source of the complaint; indication of the contested decision, decision, other act or provision; signature of the party or its legal representative or proxy; listing attachments. It should be noted that the application for mediation should indicate the area of mediation, i.e. the issues that should be clarified and discussed in the course of this proceeding, although in itself, it is not legally binding for the court ${ }^{22}$.

The complainant (plaintiff) and the body are the parties to the mediation proceedings before the administrative court. A report is drawn up from the course of the mediation proceedings, which includes: time and place of mediation; full name (registered name) of the complainant, designation of the body, as well as their addresses; name and address of the mediator; arrangements made by the parties to determine how to settle the matter; signatures of the mediator, the complainant and the body. Under the arrangements made as part of mediation proceedings, the body repeals or changes the challenged act, or performs or undertakes another action according to the circumstances of the case in terms of its jurisdiction and competence. However, if the parties do not make arrangements as to how to settle the matter, it should then be examined by the court. The act issued on the basis of the arrangements made in mediation proceedings can be appealed to the regional administrative court (voivodship court in the case of Poland) within thirty days from the date of its delivery, or performance or undertaking legal action. The court recognizes the complaint, including one lodged in the case on the act or activity in which the mediation proceedings were conducted. However, if a complaint against an act or action issued or performed on the basis of findings made in mediation proceedings is not submitted or it is dismissed, then the court discontinues proceedings in the case in which the mediation proceedings were carried out ${ }^{23}$.

\section{CONCLUSIONS}

Summarizing, an argument should be put forward that although environmental disputes are marked by a negative social charge and can be of diverse nature, there is nevertheless a number of methods and ways of their resolution, what was proved on the basis of the analysis. Resolving environmental conflicts forms part of a certain formula in the area of environmental security management, which is extremely important from the perspective of the functioning of the state and society as a whole. Regardless, education and public awareness of environmental protection are inseparable elements of environmental safety management.

At the same time, it might be worth adding that, in addition to the abovementioned methods of resolving environmental disputes, the solution limiting their creation comprises all forms of promoting environmental values and the need to preserve the natural state of the environment. To quote an example, as part of environmental security management, it is possible to organize numerous public events, lectures, etc., with a view to educating the public.

22 Ibidem, p. 69.

${ }^{23}$ Ibidem, p. 70-71. 


\section{REFERENCES}

1. Jurgilewicz M., Administracja bezpieczeństwa i obronności - wybrane aspekty [in:] Wspólna polityka bezpieczeństwa i obronności. Implikacja dla Polski, A. Letkiewicz, Z. Nowakowski, J. Rajchel (eds.), Warsaw 2011.

2. Jurgilewicz M., Wymiar unijnego bezpieczeństwa po wejściu w życie Traktatu z Lizbony [in:] UE-NATO - Strategiczne problemy bezpieczeństwa, red. naukowa T. Compa, J. Rajchel, K. Załęski, Dęblin 2012.

3. Jurgilewicz M., Dana A., Mediacja jako sposób rozwiąywania sporów prawnych, Warsaw 2015.

4. Jurgilewicz M., Mediacja w postępowaniu administracyjnym [in:] Bezpieczeństwo. Prawo. Polityka, M. Jurgilewicz, T.Z. Leszczyński, N. Malec (ed.), Kraków 2017.

5. Jurgilewicz M., Mediacja w administracji publicznej, Rzeszów 2018.M. Morawski, Wstęp do prawoznawstwa, Torun 2001.

6. Morawski L., Wstęp do prawoznawstwa, Torun 2001.

7. Niemiec W., Pacana A., Jurgilewicz O., Jurgilewicz M., Aspekty zarządzania środowiskiem w praktyce inżynierskiej, Rzeszów 2013.

8. Wojtaszczyk K.A., Majerska-Sosnowska A. (ed.), Bezpieczeństwo państwa. Wybrane problemy, Warsaw 2009.

\section{LEGAL ACTS}

1. Act of 14 June 1960. The Code of Administrative Procedure (Journal of Laws of 2017, item 1257 , as amended).

2. Act of 17 November 1964. The Code of Civil Procedure (Journal of Laws of 2018, item 1360, as amended).

3. Act of 6 June 1997. The Penal Code (Journal of Laws of 2017, item 1904, as amended).

4. Act of 30 August 2002. Law on Proceedings before Administrative Courts (Journal of Laws of 2018, item 1302, as amended).

\section{ZARZĄDZANIE BEZPIECZEŃSTWEM EKOLOGICZNYM Z PERSPEKTYWY ROZSTRZYGANIA KONFLIKTÓW EKOLOGICZNYCH}

Jednym z obowiązków państwa jest zapewnienie jego obywatelom bezpieczeństwa. Powinność ta dotyczy każdej kategorii bezpieczeństwa, w tym także bezpieczeństwa ekologicznego. Zapewnienie zatem bezpieczeństwa, które oznacza stan zabezpieczenia żywotnych interesów jednostek i państwa przed różnego rodzaju zagrożeniami, nie tylko wewnętrznymi, ale także zewnętrznymi pozwala wskazać najważniejsze komponenty bezpieczeństwa, którymi są jednostki ludzkie i ich prawa oraz swobody, jak też państwo łącznie ze swoim konstytucyjnym ustrojem, suwerennością, jak również całością terytorium. Z kolei zarządzanie bezpieczeństwem ekologicznym rozumiane jako proces, którego efektem ma być osiągnięcie wyznaczonych celów w tej sferze należałoby postrzegać także w formule rozstrzygania konfliktów. Rozstrzyganie konfliktów ekologicznych może być realizowane w ramach różnych trybów. Może to nastąpić w trybie kontraktowym, mediacyjno-koncyliacyjnym, arbitrażowym, jak również adiudykacyjnym, co w tym ostatnim przypadku ma najczęściej miejsce w praktyce, ponieważ powstały spór jest rozstrzygany na gruncie procesu sądowego, który kończy się prawomocnym orzeczeniem dając jednej ze stron poczucie tzw. wygranej. Jednakże przez 
wzgląd na dynamikę zmian legislacyjnych należy dostrzec obowiązujące od dłuższego czasu narzędzia prawne, które umożliwiają skonfliktowanym stronom rozstrzygnięcie sporu w formule ich obopólnego sukcesu. Z uwagi na fakt, iż każda ze przywołanych form rozstrzygania konfliktów ekologicznych charakteryzuje się odmiennymi mechanizmami, toteż warto poddać analizie poszczególne modele, co stało się przedmiotem rozważań w niniejszym artykule.

Słowa kluczowe: bezpieczeństwo ekologiczne, zarządzanie bezpieczeństwem, zagrożenia, konflikty.

DOI: 10.7862/rz.2018.mmr.43

Tekst złożono do redakcji: wrzesień $2018 \mathrm{r}$.

Tekst przyjęto do druku: grudzień 2018 r. 
